\section{War, Drunkenness and Suicide}

IN a recent paper (Brit. J. Inebriety, 38, $28 ; 1940$ ) based on his experience at H.M. Liverpool Prison which receives male prisoners from a wide area in the north-west of England and North Wales, Dr. Harvie K. Snell discusses the influence of the outbreak of the present War on drunkenness and attempted suicide, the connexion between which has often been stressed. Under the single heading dmunkenness he has included not only simple drunkenness but also cases described as drunk and disorderly, drunk in charge of a vehicle and those charged at the same time with begging and common assault. His figures show the somewhat surprising result that there was a definite decline during the first four months of the War as compared with the previous three years in the number of persons admitted to prison for drunken. ness or attempted suicide.

These results are in striking contrast with the late Dr. Sullivan's results concerning convictions in women for the same two offences in 1914, which both showed a marked increase after the outbreak of war, but present the same trend as the figures relating to women admitted to the Manchester Prison from an extensive area in the north-west of England and Wales for drunkenness and attempted suicide in the early months of the present War. Dr. Snell attributes the decline in the incidence both of drunkenness and of attempted suicide on the present occasion to economic and social as well as psychological causes, the former including rise in the price of liquor and the condition of the streets in the black-out period, and the latter the lesser degree of emotional strain leading to drunkenness than that which occurred in 1914 .

\section{Colonel Kenneth Macleod}

Colonel KenNeth Macleod, an eminent military surgeon and hygienist, was born in the Outer Hebrides on July 23, 1840, the son of a Free Church minister. He received his medical training in the University of Edinburgh, where he qualified in 1864. After four years service in the Indian Medical Service, he was appointed secretary to the Inspector-General of Hospitals in 1872 and held this post until 1879 . On December 1, 1879, he was made professor of anatomy in the Calcutta Medical College, a post which he held until his retirement in 1892. Macleod did much for the advancement of medicine in India. In 1869 he investigated Indian cattle plague and set about establishing facilities for veterinary research in India, which culminated in the foundation of the Bengal Veterinary College. In addition to his surgical activities, he took an active part in public work. He founded the Calcutta Medical Society, was its first secretary and later its president, and was editor of the Indian Medical Gazette during 1871-92. After his return to England on his retirement, he was appointed professor of clinical military medicine at the Army Medical Sehool at Netley, and held this post until 1905. He died on December 17, 1922.

\section{Early Man and Pleistocene Deposits in America}

Although it is established by the find in New Mexico of a Folsom projectile point embedded in fossil mammalian vertebræ that early man in America was contemporary with and hunted an extinct form of bison, the absence or ambiguous character of stratigxaphical evidence and associations of a majority of finds of early American stone age industries hitherto have made it impossible to determine with certainty either their age or their place in a cultural sequence. The relation of the Folsom point, for example, to the Yuma type, which typologically is simpler or more primitive, remains obscure, though the finds recently reported from the south-western States indicate a possibility of establishing sooner or later a cultural sequence leading up to Folsom man, and this is brought nearer to being realized by the discovery of the so-called Sandia man, whose existence is inferred from artefacts found in the basal layers of a cave of the Sandia Mountains, near Albuquerque, New Mexico. These artefacts would appear to be the earliest relics of human purposive activity as yet discovered on the American continent. Here, during the past three years, numerous relics of an extinct fauna mingled with human artefacts have been found, of which the stratigraphic sequence has been fully established in recent excavations.

Frank C. Hibben, writing in the Scientific American of July, gives a brief outline of the sequence of deposits found in the Sandia Cave. It begins with the surface deposits of dust with which were mingled pottery and other relics of the Pueblo age. Beneath this a layer of stalagmite deposited in a pluvial period sealed late Pleistocene deposits, in which debris bone fragments and soil were consolidated into a homogeneous mass by calcium carbonate. In this material were chips of flint, scrapers and points, among them the true Folsom points. Beneath this Folsom layer was a thick deposit of yellow ochreous laminated material, evidently water-borne, deposited in a second pluvial when the cave was not in use. Beneath this, and between it and the floor of the cave, was the accumulation of a dry period showing the earliest evidence of occupancy of the cave-fragments of bone, evidence of fires, and stone implements. The implements include shouldered points, entirely different from the Folsom point, and said to be comparable to European palæolithic types. By a hearth lay a blackened fragment of the jaw of a camel. It would thus appear that the evidence from the Sandia cave not only points to the existence of Folsom man in late Pleistocene times, but also has established on indubitable stratigraphic evidence the appearance of more primitive culture in a considerably earlier period, contemporary with an extinct Pleistocene fauna.

\section{The Canadian Entomological Service}

UNDER this title, Dr. Arthur Gibson, Dominion entomologist, Ottawa, has discussed the more important developments in applied entomology in Canada during the past fifty years. His paper is published in the Transactions of the Seventh 
International Congress for Entomology, held in Berlin in 1938, pp. 1429-1479. James Fletcher, in 1887, incepted studies on insects injurious to Canadian crops and in that year he became the first Dominion entomologist. Prior to this time he had acted for a fow years in an honorary capacity. On Fletcher's death Dr. Gordon Hewitt, of the University of Manchester, succeeded to the post thus vacated : he held office from 1909 until 1920. In the last-named year the death of Hewitt led to the appointment of $\mathrm{Mr}$. (now Dr.) Arthur Gibson as the Dominion entomologist.

The Canadian Entomological Service has steadily developed each year and has attained a commanding position in the Dominion Department of Agriculture at the present day. Both Fletcher and Hewitt contributed much to its growth and their good work has been worthily upheld and extended by Gibson. Field stations and laboratories are maintained at thirty different localities and there are ten plant inspection stations. When, however, it is recollected that the provinces Manitoba, Saskatchewan and Alberta alone, are larger than France, Germany and Italy combined, it will be realized that Canadian entomologists have no lack of problems to contend with. The Dominion Entomological Service now ranks as the most important of its kind in the British Empire.

\section{Vegetative Propagation in Tropical Plantations}

THE Imperial Bureau of Horticulture and Plantation Crops, East Malling, has issued Technical Communication 13 on this subject by G. St. Clair Fielden and R. J. Garner. It deals with the vegetative propagation of some fifty-five plantation crops, and follows a previous communication (issued in 1936) dealing with the vegetative propagation of some one hundred fruit varieties grown in the tropies and subtropies. The help of technical experts has been invoked for adequate treatment of such major crops as rubber, coffee, cacao, etc., while the foreign literature has been thoroughly combed for details of propagation of the less familiar, but nevertheless important, crops. One feature of the previous work, which commended it also to workers in temperate regions, is retained and considerably enlarged, namely, the section devoted to methods used in vegetative propagation. The descriptions are supported by simple, clear, line drawings of some seventeen types of graft and seven types of budding commonly used in vegetative propagation. Tropical workers will also be glad of the illustrated detail of the construction of loosely woven potting baskets which have been found so useful a substitute for pots in nursery work in the tropics. For those who wish to study originals, a list of references immediately follows the discussion on the propagation of each particular crop.

\section{Weeding Methods in Teak Plantations}

A. L. GRIfFITH, provincial sylviculturist, Madras has recently discussed an investigation into different weeding methods in the formation of teak plantations in areas with a west coast climate (Indian For. Rec., Sylviculture, 4, No. 2 ; Govt. of India Press, New
Delhi, 1939). The investigation was carried out on a number of small-scale experiments and four largescale ones. Five methods of weeding were tried. At the time, the principal method of weeding the young teak was by the expensive way of forking. The experiments carried on since 1932 have demonstrated that the method termed scraping is cheaper and as efficient on light forest soils ; and that other methods, such as the cheap weeding by weed cutting alone, are not worth while. Weed cutting by hand is by no means cheap in England. By the scraping method it is said that plantation costs are being reduced by Rs. 10 per acre and the quality is as good as formerly. The scraping is done in $4 \mathrm{ft}$. strips ( $2 \mathrm{ft}$. on each side of the line of plants). Weed growth was not cut before. The scraping is effected with an ordinary mammoty (like a pointed spade with a recurved handle), removing about $\frac{1}{2}$ in. of soil and cutting the weed roots at that depth below the original soillevel. The weeds removed are piled on the $2 \mathrm{ft}$. unweeded strips between the lines without cutting the weed growth on them. Or the operation may be carried out over the complete area, the weeds being then presumably removed.

\section{Equine Encephalomyelitis in U.S.A.}

IN an editorial article in Public Health Reports of April 5 the writer remarks that though equine encephalomyelitis may have existed for very many years in the United States, attention has recently been focused on it by the epidemic in Massachusetts in 1938 when human cases of encephalitis also occurred. There was, however, no indication of human contact infection in these cases. In 1939 only 8,000 cases of equine encephalomyelitis were reported in the United States, or only about 4 per cent of the number $(184,662)$ reported in 1938 . The incidence was $1 \cdot 1$ per 1,000 animals (horses and mules) in the affected counties and a case fatality of 30 per cent. The highest incidence was reported from counties in the far-western and Pacific States, a north-eastsouth-west strip of the central States and three Atlantic States, New Jersey, North Carolina and Florida. As in previous years, more than 90 per cent of the cases occurred in the summer or early autumn, This seasonal prevalence favours the current view that the principal means of transmission is by bloodsucking insects, especially mosquitoes. The prophylactic value of vaccination with a vaccine of chick embryo tissue is shown by the fact that the incidence of encephalomyelitis in vaccinated horses and mules was 0.37 per 1,000 in the vaccinated as compared with 1.2 in the unvaccinated. Other factors in the reduction of the disease were the retarding of insect breeding and increased resistance owing to previous attacks among the animals.

\section{Vehicle Radio-Telephone Service}

IT is reported from Pittsburgh, Pa., that the Bell Telephone Co. has applied for a permit to install transmitters and receivers on what is called a 'tie-up' with existing telephone facilities. The company has applied to the Federal Communications Commission 